\title{
NOTE
}

\section{Intra-species host specificity of HaV (Heterosigma akashiwo virus) clones}

\author{
Keizo Nagasaki*, Mineo Yamaguchi \\ Red Tide Biology Section, Red Tide Research Division, Nansei National Fisheries Research Institute, 2-17-5 Maruishi, Ohno, Saeki, \\ Hiroshima 739-04, Japan
}

\begin{abstract}
Heterosigma akashiwo virus (HaV) infecting the harmful bloom causing microalga Heterosigma akashiwo (Raphidophyceae) were isolated from coastal waters of Japan. Host specificities of the virus clones were tested against 18 strains of $H$. akashiwo isolated from coastal waters of the western part of Japan. Although all of the 14 virus clones lysed 10 of the $H$. akashiwo strains, in 4 strains no viral lysis was observed with any of the clones. The remaining $4 \mathrm{H}$. akashiwo strains were lysed by 7 to 11 of the virus clones. Further, viral lysis against $H$. akashiwo is not always complete, allowing the proliferation of surviving cells. These results indicate 2 possibilities: (1) HaVs are phenotypically diverse in terms of their host specificity; (2) $H$. akashiwo strains are phenotypically diverse in terms of their viral sensitivity. The high diversity among both the virus clones and the host strains concerning viral infection indicates that the interaction between viruses and hosts in situ appears more complicated than a simple host and pathogen relation.
\end{abstract}

KEY WORDS: HaV - Heterosigma akashiwo - Raphidophyceae Harmful algal bloom - Red tide - Virus · Host range

In recent years, viruses infecting 5 different eukaryotic marine microalgae have been isolated: Micromonas pusilla (Prasinophyceae), Aureococcus anophagefferens (Chrysophyceae), Chrysochromulina spp. (Prymnesiophyceae), Phaeocystis pouchetii (Prymnesiophyceae) and Heterosigma akashiwo (Raphidophyceae) (Cottrell \& Suttle 1991, Milligan \& Cosper 1994, Suttle \& Chan 1995, Jacobsen et al. 1996, Nagasaki \& Yamaguchi 1997). Their host range appears to be quite narrow as they lyse only the host species used in each screening experiment with the exception of a virus infectious to both $C$. brevifilum and $C$. strobilus (Suttle \& Chan 1995). However, there have been few

·E-mail: nagasaki@nnf.affrc.go.jp surveys of any intra-species host specificity, i.e. the strain specificity of these viruses.

We have recently reported on the strain specificity of the Heterosigma akashiwo virus ( $\mathrm{HaV}$ ) clone GSNOU30, designated as 'HaV08' in the present paper (see Table 1). In the previous study, this clone was lytic to only 2 of 5 strains of $H$. akashiwo tested, suggesting marked phenotypic diversity among $H$. akashiwo strains (Nagasaki \& Yamaguchi 1997). In the present note, we describe the lytic activity of 14 clones of $\mathrm{HaV}$ against 18 clonal strains of $H$. akashiwo isolated from coastal waters in western Japan to examine the diversity of both virus clones and algal strains in terms of infectivity and susceptibility.

Seawater samples collected in Unoshima Port (Fukuoka Prefecture) on 24 June 1996 and Nomi Bay (Kochi Prefecture) on 11 July 1996, which contained 17000 and 35400 cells $\mathrm{ml}^{-1}$ of Heterosigma akashiwo, respectively, were initially kept at $4^{\circ} \mathrm{C}$ and sent to the laboratory within $24 \mathrm{~h}$. They were UV treated as described previously (Nagasaki \& Yamaguchi 1997) and screened for the presence of viruses lytic to H. akashiwo strains UR94, GS95, KG95, KM95 or H93616. The seawater sample collected in northern Hiroshima Bay (Hiroshima Prefecture) on 3 July 1996, containing 700 cells $\mathrm{ml}^{-1}$ of $H$. akashiwo, was concentrated 127 -fold using a Hollow Fiber Cartridge system (100000 MW cutoff, AMICON) and filtered through a $0.2 \mu \mathrm{m}$ Nuclepore membrane filter. The filtrate was also screened for the presence of algicidal factors against the 5 strains of $H$. akashiwo, and they were isolated by performing the extinction dilution method twice (Nagasaki \& Yamaguchi 1997). The MPN (most probable number) of algicidal units in each extinction dilution assay was calculated using the computer program developed by Nishihara et al. (1986). MPN of 
Table 1. Heterosigma akashiwo. Origin of virus clones isolated in the present study. Host strain: H. akashiwo strain used as a host in the screening experiment; irradiation time: exposure time to UV irradiation (see Nagasaki \& Yamaguchi 1997)

\begin{tabular}{|c|c|c|c|}
\hline $\begin{array}{l}\text { Virus } \\
\text { clone }\end{array}$ & $\begin{array}{l}\text { Host } \\
\text { strain }\end{array}$ & $\begin{array}{l}\text { Original } \\
\text { location }\end{array}$ & $\begin{array}{l}\text { Irradiation } \\
\text { time }(\mathrm{s})\end{array}$ \\
\hline Hav01a & H93616 & Unoshima Port & 0 \\
\hline HaV02 & H93616 & Unoshima Port & 30 \\
\hline $\mathrm{HaV03}^{\mathrm{a}}$ & H93616 & Unoshima Port & 60 \\
\hline Hav04 & H93616 & Unoshima Port & 120 \\
\hline $\mathrm{HaV05}$ & UR94 & Unoshima Port & 60 \\
\hline Havo6 & UR94 & Unoshima Port & 90 \\
\hline $\mathrm{HaV} 07^{\circ}$ & GS95 & Unoshima Port & 90 \\
\hline HaV08 & GS95 & Nomi Bay & 30 \\
\hline Havog & H93616 & Nomi Bay & 0 \\
\hline $\mathrm{HaV} 10^{\mathrm{a}}$ & H93616 & Nomi Bay & 120 \\
\hline HaV 11 & UR94 & Nomi Bay & 0 \\
\hline Hav12 & UR94 & Nomi Bay & 30 \\
\hline HaV13 & UR94 & Nomi Bay & 60 \\
\hline $\mathrm{HaV} 14^{\mathrm{d}}$ & H93616 & Hiroshima Bay & $0^{b}$ \\
\hline \multicolumn{4}{|c|}{${ }^{a}$ Not axenic } \\
\hline \multicolumn{4}{|c|}{$\begin{array}{l}\text { bisolated from the seawater sample concentrated by ultra- } \\
\text { filtration. }\end{array}$} \\
\hline
\end{tabular}

algicidal factors in the resultant lysates of the initial screening procedure was estimated at $7.18 \times 10^{5}$ to $9.82 \times 10^{7} \mathrm{ml}^{-1}$.
In the present screening experiment, 32 algicidal factors were isolated. Considering their morphological features, DAPI stainability and fulfillment of Koch's postulate, they are concluded to be viruses infectious to Heterosigma akashiwo (HaV). Although, in the screening procedure, UV treatment was performed in order to induce the temperate virus in $H$. akashiwo cells into lytic virus, either the practical effect of UV or the origin of the viruses is still unknown.

Among the algicidal factors, 14 viruses were examined for their host specificity against Heterosigma akashiwo strains. As the probability that the isolated viruses originated from more than 1 algicidal factor is $<0.060$, we tentatively regarded them as HaV clones. Designation of the $\mathrm{HaV}$ clones used in the present study is shown in Table 1. In spite of filtration through a $0.2 \mu \mathrm{m}$ filter, 6 of them were not axenic (see Table 1).

Host specificity of each virus clone was examined by using 18 strains of Heterosigma akashiwo as hosts in the present experiment (Table 2). They are clonal and axenic except for strain H96617-3, which is contaminated with bacteria. The cultures were grown at $20^{\circ} \mathrm{C}$ in modified SWM3 medium (Chen et al. 1969, Itoh \& Imai 1987) enriched with $2 \mathrm{nM} \mathrm{Na}_{2} \mathrm{SeO}_{3}$ under a 14:10 h light:dark cycle of ca $45 \mu \mathrm{mol}$ photons $\mathrm{m}^{-2} \mathrm{~s}^{-1}$ using cool white fluorescent illumination. In the present experiment, the original stocks of HaV clones were inoculated to their host cultures afresh, and the

Table 2. Lytic activity of $14 \mathrm{HaV}$ clones against 18 strains of Heterosigma akashiwo. Origin of each virus clone is shown in Table 1. Note that $H$. akashiwo strains even from the same origin (ex. H96617-3 and H96617-5, BZ96625-1 and BZ96625-3) can be different in terms of viral sensitivity. The cross-assay was carried out twice. ++: complete lysis; +: partial lysis; -: no algal lysis observed; ( ): no lytic activity was detected in one of the duplicate assays

\begin{tabular}{|c|c|c|c|c|c|c|c|c|c|c|c|c|c|c|c|}
\hline $\begin{array}{l}\text { Heterosigma } \\
\text { akashiwo } \\
\text { strain }\end{array}$ & $\begin{array}{l}\text { Locality } \\
\text { (isolation date) }\end{array}$ & $\begin{array}{c}\mathrm{HaV} \\
01\end{array}$ & $\begin{array}{c}\mathrm{HaV} \\
02\end{array}$ & $\begin{array}{c}\mathrm{HaV} \\
03\end{array}$ & $\begin{array}{c}\mathrm{HaV} \\
04\end{array}$ & $\begin{array}{c}\mathrm{HaV} \\
05\end{array}$ & $\begin{array}{c}\mathrm{HaV} \\
06\end{array}$ & $\begin{array}{l}\text { Lytic } \\
\mathrm{HaV} \\
07\end{array}$ & $\begin{array}{c}\text { activit } \\
\mathrm{HaV} \\
08\end{array}$ & $\begin{array}{c}\mathrm{Y} \\
\mathrm{HaV} \\
09\end{array}$ & $\begin{array}{c}\mathrm{HaV} \\
10\end{array}$ & $\begin{array}{c}\mathrm{HaV} \\
11\end{array}$ & $\begin{array}{l}\mathrm{HaV} \\
12\end{array}$ & $\begin{array}{c}\mathrm{HaV} \\
13\end{array}$ & $\begin{array}{c}\mathrm{HaV} \\
14\end{array}$ \\
\hline GKB-666 & Gokasho Bay (Jun 1966) & ++ & + & + & + & + & + & ++ & + & + & + & + & + & + & ++ \\
\hline GS95 & Gokasho Bay (May 1995) & ++ & + & ++ & + & ++ & ++ & ++ & ++ & + & ++ & ++ & ++ & + & ++ \\
\hline H846 & Hiroshima Bay (Jun 1984) & ++ & ++ & + & + & + & + & ++ & ++ & + & + & + & + & + & ++ \\
\hline $\mathrm{H} 492$ & Hiroshima Bay (May 1992) & ++ & - & - & ++ & ++ & ++ & ++ & ++ & + & t+ & + & ++ & ++ & - \\
\hline $\mathrm{H} 9361.6^{\mathrm{d}}$ & Hiroshima Bay (Jun 1993) & ++ & ++ & ++ & + & ++ & ++ & ++ & ++ & ++ & ++ & ++ & ++ & ++ & ++ \\
\hline $\mathrm{H} 94222$ & Hiroshima Bay (Feb 1994) & $(+)$ & + & - & - & + & + & - & - & + & - & - & + & + & - \\
\hline H94608 & Hiroshima Bay (Jun 1994) & - & - & - & - & - & - & - & - & - & - & - & - & - & - \\
\hline H95623 & Hiroshima Bay (Jun 1995) & - & - & - & - & - & - & - & - & - & - & - & - & - & - \\
\hline H96611 & Hiroshima Bay (Jun 1996) & ++ & ++ & ++ & + & ++ & + & ++ & ++ & + & ++ & $+t$ & + & + & ++ \\
\hline 196013 & IIroshima Bay (Jun 1996 ) & ++ & ++ & ++ & + & ++ & $+t$ & ++ & ++ & ++ & ++ & ++ & ++ & + & ++ \\
\hline $\mathrm{H} 96617-3^{b}$ & Hiroshima Bay (Jun 1996) & + & - & - & - & ++ & ++ & - & - & ++ & - & ++ & ++ & ++ & - \\
\hline H96617-5 & Hiroshima Bay (Jun 1996) & - & - & - & - & - & - & - & - & - & - & - & - & - & - \\
\hline BZ96625-1 & Unoshima Port (Jun 1996) & ++ & + & + & + & + & + & ++ & ++ & + & + & ++ & + & + & ++ \\
\hline$B Z 96625-3$ & Unoshima Port (Jun 1996) & - & - & - & - & - & - & - & - & - & - & - & - & - & - \\
\hline $\mathrm{KM} 95^{\mathrm{d}}$ & Yatsushiro-Kai (Apr 1995) & ++ & ++ & + & + & + & + & ++ & ++ & + & + & ++ & + & ++ & ++ \\
\hline KG95 & Kagoshima Bay (Apr 1995) & ++ & ++ & ++ & ++ & + & ++ & ++ & ++ & ++ & ++ & ++ & + & + & ++ \\
\hline UR94 ${ }^{\circ}$ & Uranouchi Bay (May 1994) & - & - & + & + & ++ & ++ & ++ & $(++)$ & ++ & + & ++ & ++ & + & - \\
\hline NM96 & Nomi Bay (Jul 1996) & + & ++ & + & + & ++ & ++ & ++ & ++ & + & + & ++ & ++ & + & ++ \\
\hline
\end{tabular}


resultant viral lysates were used as the inocula. The susceptibility of hosts to the isolated viruses was tested by adding $50 \mu \mathrm{ll}$ of the lysate to $1 \mathrm{ml}$ of the exponentially growing strains of $H$. akashiwo (Table 2). The cultures were observed by light microscopy every $2 \mathrm{~d}$ in principle, and cultures that were not lysed $14 \mathrm{~d}$ after the viral inoculation were considered to be non-susceptible to the virus clone. Concurrently, the survival of the host cells in the lysed culture was also checked by optical microscopy.

All cross-assays were run in duplicate, and essentially the same results were obtained from both replicates, except for 2 crosses where no lytic activity was detected in 1 of the assays (see Table 2). From the viewpoint of viral infectivity, all of the virus clones were infectious to $10-14$ of the 18 Heterosigma akashiwo strains tested. Even among the virus clones isolated from the same seawater sample, the host specificity pattern was different, e.g. among the 7 virus clones (HaV01 to HaV07) from Unoshima Port, HaV02 and HaV03 lacked infectivity against $H$. akashiwo strain $\mathrm{H} 492$ which the other clones lysed completely (Table 2). Considering that 10 of the 14 virus clones were irradiated with UV, which could be a possible factor causing genetic mutation, it appears difficult simply comparing the infectivity of the virus clones originated from the UV irradiated seawater sample. Notwithstanding, even though we compare the natural virus clones, HaV09 and HaV11, which were isolated from the same seawater sample of Nomi Bay without UV treatment (Table 1), their algicidity against $H$. akashiwo strain H94222 is different (Tables 1 \& 2). This fact suggests that there exist $\mathrm{HaV}$ clones which are phenotypically different in terms of host specificity in the natural environment. Both the phenotypic and genetic diversity of viruses infecting Micromonas pusilla (MpV) were reported by Cottrell \& Suttle (1991), who showed variations in the RFLP pattern and main protein banding pattern even among virus clones from the same origin. To genetically substantiate the phenotypic diversity among $\mathrm{HaV}$ clones, a similar approach will be required.

On the other hand, susceptibility spectra of Heterosigma akashiwo strains to viral infection were still more diverse. Practically, in the duplicated assays to test the host range of the virus clones, in 4 of the $H$. akashiwo strains, H94608, H95623, H96617-5 and BZ96625-3, no symptom of viral lysis or appearance of immotile cells was observed, suggesting that some mechanism to avoid infection occurs in these strains. The other $4 H$. akashiwo strains were sensitive to $7-11$ of the virus clones, and the remaining 10 were lysed by all of the virus clones (Table 2). However, the pattern was complicated by the different sensitivities even between $H$. akashiwo strains from the same origin, e.g.
H96617-3 and H96617-5, BZ96625-1 and BZ96625-3 (see Table 2). These results suggest that a phenotypic diversity in terms of sensitivity against viral infection exists in the speries $H$. akashiwo.

In addition, the individual cross reactions between a virus clone and an algal strain were highly diverse: complete lysis, partial lysis or no effect (Table 2). During the lytic process of Heterosigma akashiwo by viral infection, the algal cell becomes roundish, loses motility, and finally collapses (Nagasaki \& Yamaguchi 1997). However, some cells often survived in the lysed culture, which sometimes densely proliferated again (i.e. partial lysis). The mechanism for resistance or survival of these cells in the partial lysis strains is a question requiring further study.

In conclusion, 2 possibilities may occur from the present experiments: (1) HaVs are phenotypically diverse in terms of their host specificity, (2) Heterosigma akashiwo strains are phenotypically diverse in terms of their sensitivity to viral infection. As the occurrence of host range mutations of viruses and of host cells in laboratory culture has been shown in case of $\mathrm{MpV}$ (Waters \& Chan 1982), this kind of phenotypical change might be involved in the characteristics of algal viruses. Considering the high diversity among both the host strains and the virus clones, this may be an important factor in sustaining their coexistence in natural environment. In addition, viral lysis against $H$. akashiwo was in some cases only partial allowing the proliferation of survival cells. Therefore, viral impacts on natural algal populations can be considered to be potentially more complex than those as simple pathogenic agents.

Acknowledgements. Dr H. Iwasaki (formerly Mie Univ.) graciously provided the Heterosigma akashiwo strain GKB-666. We express our sincere thanks to Mr S. Oda, Kochi Prefectural Fisheries Experimental Station, and Mr T Etoh, Fukuoka Fisheries and Marine Technology Research Center, for providing the seawater samples. Thanks are also extended to Dr S. Norland (Univ. Bergen) for preparation of MPN-calculation computer program, and Mr S. Itakura (Nansei National Fish. Res. Inst.) for isolation of several strains of $H$. akashiwo. This work was supported in part by funding from the Ministry of Agriculture, Forestry and Fisheries of Japan.

\section{LITERATURE CITED}

Chen LCM, Edelstein T, McLachlan J (1969) Bonnemaisonia hamifera Hariot in nature and in culture. J Phycol 5: 211-220

Cottrell MT, Suttle CA (1991) Wide-spread occurrence and clonal variation in viruses which cause lysis of a cosmopolitan, eukaryotic marine phytoplankter, Micromonas pusilla. Mar Ecol Prog Ser 78:1-9

Itoh K, Imai I (1987) Rafido so (Raphidophyceae). In: Japan fisheries resource conservation association (ed) A guide for studies of red tide organisms. Shuwa, Tokyo, p 122-130 (in Japanese)

Jacobsen A, Bratbak G, Heldal M (1996) Isolation and charac- 
terization of a virus infecting Phaeocystis pouchetii (Haptophyceae). J Phycol 32:923-927

Milligan KLD, Cosper EM (1994) Isolation of virus capable of lysing the brown tide microalga, Aureococcus anophagefferens. Science 266:805-807

Nagasaki K, Yamaguchi M (1997) Isolation of a virus infectious to the harmful bloom causing microalga Heterosigma akashiwo (Raphidophyceae). Aquat Microb Ecol 13: $135-140$

Nishihara T, Kurano N, Shinoda S (1986) Calculation of most

Editorial responsibility: Gunnar Bratbak,

Bergen, Norway probable number for enumeration of bacteria on a microcomputer. Eisei Kagaku 32:226-228 (in Japanese with English abstract)

Suttle CA, Chan AM (1995) Viruses infecting the marine Prymnesiophyte Chrysochromulina spp.: isolation, preliminary characterization and natural abundance. Mar Ecol Prog Ser 118:275-282

Waters RE, Chan AT (1982) Micromonas pusilla virus: the virus growth cycle and associated physiological events within the host cells; host range mutation. J Gen Virol 63:199-206

Submitted: June 7, 1997, Accepted: August 27, 1997

Proofs received from author(s): October 29, 1997 